\title{
“Environmental Migration" as ADVOCACY: Is IT GOING TO WORK?
}

\author{
Benoît MAYer
}

\begin{abstract}
Can normative arguments for a governance of environmental migration succeed? The present analysis applies constructivist theories on norm entrepreneurship to the debate on the governance of environmental migration. Throughout the analysis, it appears that "environmental migration" is not constructed by one single, coherent norm entrepreneur. Rather, one may distinguish four normative enterprises that compete to use similar notions in the pursuit of divergent goals. They frame the issue of "environmental migration," alternatively, as one of humanitarian assistance, forced migration, environmental sustainability, or international security. The article analyzes the prospect of each individual normative enterprise and their interactions. It concludes that norm entrepreneurs elaborating on a language of international security will likely have the greatest impact on the governance of environmental migration. Other normative enterprises are already permeated by the dominant language of fears.
\end{abstract}

\section{Résumé}

L'argument normatif quant à une gouvernance des migrations environnementales peut-il convaincre? Cet article propose une analyse de la gouvernance des migrations environnementales basée sur la théorie constructiviste de l'«entreprise normative». Au travers de cette analyse, il apparait que les "migrations environnementales» ne sont pas le fruit d'un seul acteur, mais plutôt de quatre groupes de pression distincts. Ces groupes de pression définissent le problème des "migrations environnementales", alternativement, comme un problème d'assistance humanitaire, de migrations forcées, de protection de l'environnement, ou de sécurité internationale. Cet article conclue que les entrepreneurs normatifs qui s'appuient sur le concept de sécurité internationale sont sans doute ceux qui auront le plus grand impact sur la gouvernance des migrations environnementales. Les autres entreprises normatives ont déjà commencé à céder la voie au discours sécuritaire dominant.

There is nothing either good or bad, but thinking makes it so. -Hamlet, 2.2

\section{Introduction}

The great causes of humanity are defined through a sociohistorical process of argumentation. Of late, it has become common to plead for specific efforts in relation to "environmental migration," in particular through international norms. The promoters of these normative arguments are not only academics, ${ }^{1}$ but also NGOs, ${ }^{2}$ international organizations, ${ }^{3}$ and (more and more) states. ${ }^{4}$ Yet the debate has centred on the ends that one should strive for, and less on the ways to achieve them, despite the saying that "a goal without a plan is just a wish." ${ }^{5}$ For the ethical arguments at stake to become something more than a wish, it is necessary to develop pragmatic research that would identify which argumentative strategies work, which do not work, and which are counter-productive-that is, an argumentative plan.

This article is a modest attempt at sparking a cold analysis within this debate. Such a cold analysis would map the discursive arena by indicating the destinations that advocates would likely reach if they opted for a specific argumentative route, the perils that they would face en route, and perhaps the shortcuts that they could take to reach their destination in time.

For that purpose, this article is inspired by the "constructivist turn" of international relations studies, which demonstrated that, in the pursuit of international relations, "social construction matters." The constructivist perspective is thus an attempt at introducing Derrida's notion of 
deconstruction into the analysis of international relations, often along with Habermas's theory of communicative action. ${ }^{7}$ In particular, this article makes use of a theoretical framework on norm entrepreneurship developed during the late 1990 s and early 2000 s.

The discussion is structured as follows. The first section reviews the constructivist literature, with a focus on theories on norm entrepreneurship. The second section analyzes how the issue of "environmental migration" has been framed. The third section discusses the individual prospects of four different normative enterprises. The last section questions the interactions among these normative enterprises.

Constructivism has developed through analytical studies on historical examples. In retrospect, there is an unavoidable tendency to elude unsuccessful arguments and to "flatten" successful ones. Unsurprisingly, things appear considerably murkier, sometimes undecipherable, when the same theories are applied prospectively to arguments in the making. In particular, complications result from the existence of competing normative enterprises that approach "environmental migration" in different ways and suggest diverging responses.

\section{How Do New Norms Emerge?}

At the end of the 1990s, the constructivist literature had reconceptualized norms, not as a given, but rather as the outcome of a social interaction-a process of transforming a mere possibility into a "should be" and finally into an

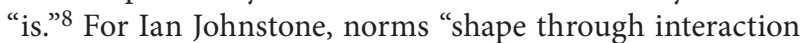
within and between states, and in a transnational process that involves representatives of NGOs, the private sector, and officials of international organizations, as well as states."

Martha Finnemore and Kathryn Sikkink developed a theory of the "life cycle" of norms, constituting of three phases: "emergence," "cascade," and "internalization."10 Each of these steps is supported by a distinct social process involving different actors. Firstly, "norm entrepreneurs with organizational platforms" gain the support of critical states, thus allowing the emergence of norms on global agendas. Secondly, "states, international organizations [and] networks" rally norm-breakers through "socialization, institutionalization [and] demonstration." Finally, "law, professions," and "bureaucracies" internalize the norms as habits: a new norm is born. ${ }^{11}$

Johnstone defines the "norm entrepreneurs" as "actors with a cause who mobilize support for that cause and seek to have it crystallized as an accepted standard of behaviour." 12 They can be relatively powerful leaders, head of states, or UN secretaries general, or influential advocates such as Henri Dunant. ${ }^{13}$ If individual qualities are certainly a must, Finnemore and Sikkink insist that "all norm promoters at the international level need some kind of organizational platform from and through which they promote their norms." 14 These organizational platforms can consist of NGOs, ${ }^{15}$ intergovernmental organizations, ${ }^{16}$ or states. ${ }^{17}$ However, some authors conceive of institutional "norm entrepreneurs" such as states, the EU, or international organizations. $^{18}$

Because norm entrepreneurship is essentially an attempt of the relatively powerless to affect the more powerful, norm entrepreneurs cannot use force: arguments are their only means. The analysis of norm entrepreneurship relates closely to communication studies, in particular in the work of Risse and Crawford. ${ }^{19}$ Risse argues that social action cannot be understood through a pure "logic of appropriateness"; rather, a "logic of truth seeking and arguing" should also be part of the picture. Accordingly, "arguing constitutes a learning mechanism by which actors acquire new information, evaluate their interests in light of new empirical and moral knowledge, and-most importantly_can reflexively and collectively assess the validity claims of norms and standards of appropriate behaviour." 20

Crawford adopts a broader conception of an "argument." Risse-highly influenced by Habermas's theory of communicative action-understands the logic of arguing as a rational process through which truth tends to emerge. Crawford's reception of Habermas is more cautious. For her, an argument is "an effort to persuade others to see the world in a particular way and to act in accordance with the conclusion that follows from the argument." 21 This already suggests that an argument does not need to be purely rational, as an argument is accordingly defined by its end rather than by its form. Crawford sketches a typology of arguments that distinguishes "practical," "scientific," "identity," and "ethical" arguments, but she also identifies the underlying "meta arguments ... about whether we should have an argument and what that argument should be about." 22

Identifying "meta-arguments" allows Crawford to explain the limits of argument: up to where actors are ready to be convinced. Evidently, international relations are not fully comprehended within the ambit of language ethics. Habermas's theory of communicative action roams the constructivist turn in international relations studies, yet this theory is not always the appropriate method of analysis-one may even argue that Habermas meant to develop a normative rather than a descriptive theory. ${ }^{23}$ Arguments often depend not only on their internal validity as revealed by the discourse, but also on extrinsic elements such as the mere readiness of the (potential) interlocutors to be persuaded. Risse recognizes the issue of a limited openness to 
persuasion. He distinguishes between three communicative behaviours: (1) "bargaining on the basis of fixed preferences," limited to "exchanging information about preferences, making promises, or threatening"; (2) "rhetorical action" supposing the strategic use of arguments to convince the other but with little willingness to change one's own opinion; and (3) "true reasoning" resulting from a "behavior oriented toward reaching a common understanding" where Habermas's theory on communicative action applies fully. ${ }^{24}$ However, Risse does not explain why actors opt for one or another communicative behaviour. Crawford prefers to consider a continuum of communicative settings that situate an actor's behaviour in a conception of "social action" as "complex, consisting of communication, reflection, decision, and coordination with others." The continuum extends from circumstances where "there is no argument (killing and compulsion)" to circumstances where "there is only argument (discourse ethics)." 25

Thus, this theoretical framework also hints at psychological studies on how decisions are made, in particular on the influence of emotional affects. Such works oppose the "rational processing system," which is "analytical, logical and deliberative" and "encodes reality in abstract symbols, worlds and numbers," to the "experiential system," "holistic, affective and intuitive," which "encodes reality in concrete images, metaphors and narratives linked in associative networks." 26 In particular, Epstein highlights the point that "experientially derived knowledge is often more compelling and more likely to influence behavior than is abstract knowledge." 27 Reflecting such psychological studies, constructivist authors have denounced the assumption of a cold rationality of the actors. In particular, Finnemore and Sikkink note that "politics without passion ... is hardly the politics of the world in which we live." They emphasize the need to "pay ... more attention to studies in psychology, particularly work on the roles of affect, empathy, conformity, and esteem." 28

It is precisely in this direction that Crawford turns. Reverting to Aristotle, she considers Homo politicus as "a reasoning actor, not a rational one." 29 She submits that "argument and persuasion are characterized by emotion and normative concerns as well as by rational or logical process." 30 Therefore, she extends the scope of argument to emotions, both as "barriers and openings to arguments": 31 it is because of their emotions that actors are receptive to arguments. Thus, according to Crawford, "actors make their choice about what mode of action to pursue-say the choice between strategic action (coercion or killing) and deliberation-based on their emotional relationship with the other and their sense of what is normatively right in a particular setting." 32 Because emotions contribute to defining the actors' communicative behaviour, so, too, do spontaneous moral conceptions (as opposed to reasoned ethics): "Actors judge a good argument not just by its practicality and truth value, but by what we consider is normatively right and how following it would make us feel." 33

Beyond emotions, another finding of the constructivist literature is the importance of culture. Both Risse and Crawford highlight the role of a common cultural background as a condition for argument, referring to Plato's "enchantment," Foucault's "governmentality," and Habermas's "common lifeworld" quite interchangeably: "Without language and taken for granted beliefs we could not have coherent arguments." 34 As culture extends, lifeworld limits the scope for arguments: more is taken for granted and less is open to discussion. Yet, through metaarguments, lifeworld "can be problematized or denormalized and hence opened up to arguments and persuasion." 35 Crawford notes, however, that international relations remain highly under-institutionalized when compared with an ideal-typical nation-state with high cultural integration. Despite the existence of international "deliberative institutions," she notes, "lifeworlds are thicker in regions ... and arguments across lifeworlds are often incomprehensible or plagued with misunderstanding." 36

Beyond rationality, emotions, and culture, constructivists recognize that "some domestic norms appear more likely candidates for internationalization than others." 37 This is because structural elements affect the reception of arguments. Hinting at communication studies, Finnemore and Sikkink argue that the success of an argument depends on the capacity of norm entrepreneurs to frame it within an efficient message: arguments that are "clear and specific, rather than ambiguous and complex" may have more chance of being understood and accepted. ${ }^{38}$ For Crawford, who speaks matters as well, especially with regard to the different "emotional relationships" (e.g., trust, empathy or "extreme fear") woven with different potential norm entrepreneurs. ${ }^{39}$ Furthermore, constructivist studies suggest that the substance of the argument also influences its prospectspositively if the argument participates in "a long-term trend toward humanizing the 'other,' or 'moral progress." 40 Lastly, material interests matter too, as well as actors' knowledge of their interests: Risse shows that "the more actors are uncertain about their interests and even identities," the more arguing processes are likely to occur. ${ }^{41} \mathrm{With}$ an optimistic view, Finnemore and Sikkink highlight the importance of the "use of expertise and information to change the behavior of other actors" and the "support of state actors to endorse their norms and make norm socialization a part of their agenda." 42 One may, however, imagine circumstances 
where a veil of ignorance facilitates a consensus or, at least, a fair consensus.

\section{Framing "Environmental Migration" as an Issue Alarmists versus Skeptics}

The debate on climate migration has often been conceived as the continuous opposition of two schools of thought with different disciplinary backgrounds. ${ }^{43}$ On the one hand, the "maximalist" or "alarmist" school, dominated by environmental scholars, has prospered through the release of adventurous estimates and predictions of the numbers of "environmental refugees." ${ }^{4}$ On the other hand, the "minimalist" or "skeptical" school (indeed a critique of the former), led by migration experts, highlighted the complex ways through which environmental change may induce, or prevent, different forms of migrations. The minimalists showed that the migratory effects of environmental changes depend largely on economic, social, political, and demographic factors. As a recent report put it, "The range and complexity of the interactions between [environmental, economic, social, and political] drivers means that it will rarely be possible to distinguish individuals for whom environmental factors are the sole driver ('environmental migrants')." 45

Although the maximalist school has had very little to respond to the minimalist critique, its ideas remain surprisingly influential in public debate and in law and political science scholarship. ${ }^{46}$ Gemenne related this epistemological divide to different political objectives: accordingly, the maximalist "coalition" advocated for environmental protection, whereas the minimalist one focused on a notion of "protection." ${ }^{\prime 7}$ As a first analysis, the maintained influence of the maximalist school, despite its essential flaws, reflects the discrepancy between the scientific accuracy of an academic argument and its success, especially in political debates.

\section{Four Collective Norm Entrepreneurs}

This fundamental opposition between two schools of thought is an important starting point, but it is insufficient for our present purpose. Some narratives do not easily fit within a strict dichotomy between the "alarmist" and the "skeptical" coalitions. In one of the few sociological analyses of the debate, Vlassopoulou identified three sectors: to the "asylum" and "environmental" that correspond broadly to the two schools of thoughts, she added the "humanitarian" sector, which approaches environmental migration as part of the governance of natural disasters. ${ }^{48}$

I argue that four broad normative enterprises can be distinguished. They relate to (1) international assistance, (2) the protection of forced migrants, (3) environmental sustainability, and (4) international security. At the risk of oversimplifying the question, it might be argued that the first two projects elaborate on the skeptical views, whereas the last two groups rather follow the assumptions of the alarmist school. There are significant contentions within each normative enterprise, but I argue that each group of advocates is broadly united by a common goal, a common language and culture, a similar way of framing environmental migration as a governance issue, and overall a comparable argument. Each of these groups of advocates can be analyzed as a roughly coherent norm entrepreneur.

These normative enterprises pre-existed the discourse on environmental migration: in each case, environmental migration is a flagship rather than an ultimate goal. In other words, environmental migration is an intermediary step to grander projects-a strategic symbolic position from which each norm entrepreneur would dominate other argumentative battlefields.

The first enterprise promotes norms on international assistance. Leading institutions include UN agencies (e.g., UNDP), ${ }^{49}$ international development agencies (e.g., World Bank, Asian Development Bank), ${ }^{50}$ as well as multiple NGOs (e.g., CARE, Christian Aid). ${ }^{51}$ They approach environmental migration through the notions of "disaster" and "human vulnerability," adopting languages of rights and development, but also more specifically of "disaster risk-reduction" and "resilience." This is concededly a broad group of heterogeneous agents, with significant differences in particular between the purely humanitarian actors and those working on development activities. However, those two fields have significant overlaps. In particular, as Minn notes, both "entail relationships between individuals and institutions in wealthy and impoverished countries, and have developed sizable infrastructures to facilitate these relationships and the processes that emerge from them." 52 Both frame "environmental migration" as a "disaster," although humanitarianism aims at responding to urgent needs following a disaster, whereas development aims at reducing the risk of, or recovering from, such a disaster. The need to coordinate humanitarian assistance and aid to development is well recognized.

The second normative enterprise promotes the protection of forced migrants. Its advocates feature in particular many academics (e.g., Alexander Betts, Stephen Castles, Graeme Hugo, Jane McAdam) and two international institutions (UNHCR and IOM). Here, the discourse on "environmental" or "climate refugees" follows and greatly reinforces previous arguments for the protection of "economic refugees." The argument revolves around the analogy between environmentally induced forced migrants and refugees as people in need of international protection. 
The third normative enterprise promotes the imperative of environmental sustainability. It puts together academics (e.g., Frank Biermann and Ingrid Boas, Norman Myers), environmental NGOs (e.g., Environmental Justice Foundation, ${ }^{53}$ Equity BD), and some international institutions (UNEP, UNFCCC), with a support of some developing states (in particular AOSIS). These actors are interested mostly in the roots of environmental migration, either in terms of environmental protection (climate change mitigation) or of human resilience (climate change adaptation in situ). In fact, this normative enterprise often focuses on "climate migration" as a sub-issue circumscribed to instances of environmental migration that are attributed to anthropogenic global environmental change. It builds on "responsibility" and "climate justice," from which a duty to cease the harming conduct and to repair the injuries is inferred.

Lastly, the fourth normative enterprise promotes the reinforcement of national defence capabilities broadly understood, ranging from the military to border-control technologies, intelligence, etc. Its advocates are mainly members of the traditional security community (e.g., CAN Corporation, Jane's Information Group), ${ }^{54}$ international institutions (e.g., the Security Council), ${ }^{55}$ think tanks and researchers, ${ }^{56}$ influential national institutions, and some industrial lobbies. ${ }^{57}$ Arguing that environmental migration may give rise to illegal migration, international criminality, terrorism, and conflicts, these actors call for preventive action, including investment in strategic partnerships with transit countries, border-control technologies, and reinforcement of military presence overseas. ${ }^{58}$

\section{Constructing Identities, Roles, and Interests}

Environmental migrants do not take an active role in any of the four collective normative enterprises. Yet their absence from the debate often goes remarkably unremarked. ${ }^{59}$ Even within their own states, environmental migrants hardly have any impact on the political agenda. ${ }^{60}$ This can be explained by what Crawford calls the "barrier of simple participation": as she notes, "The poor cannot be heard unless the media or the powerful publicize their arguments." 61 Precisely: empirical studies show that environmental inducement to migration affects in particular the poor, who are less resilient and often more exposed to environmental changes. ${ }^{62}$ Furthermore, environmental migrants lack a collective identity, prerequisite to any political existence as a group. "Environmental migrants" do not exist as anything approaching a socially constituted group that could have its voice heard; in fact, it must be rehearsed, and it is often impossible even "to distinguish individuals for whom environmental factors are the sole driver." 63
This absence of those most directly concerned by the debate raises moral issues, ${ }^{64}$ all the more because it contributes significantly to framing the debate: for whose benefit are the arguments on environmental migration developed? The identity of "environmental migrants" has not come from below: it has been imposed from above. The definition of this identity is an instance of competition amongst the four normative enterprises. ${ }^{65}$ Each narrative is based on a different construction of "environmental migration," but in each case this figure is imagined in opposition from "us." Such dichotomies strive only because the "others" are voiceless. The first three collective norm entrepreneurs claim that they speak on behalf of environmental migrants, as they claim to emphasize respectively their need for norms institutionalizing international solidarity, their need for norms protecting all forced migrants, and their need for norms responding to climate change. The last collective norm entrepreneur constructs "environmental migrants" as at least potentially an enemy.

Firstly, the humanitarian normative enterprise construes a relation between the mighty, valiant saviours and the vulnerable, passive others presumably waiting to be saved. The success of the narrative in framing an argument depends on the strength of empathy, stemming from the perception of a link of kinship between the interlocutor and the "victims." Thus, Strömberg shows that "donors ... give more to countries that lie closer, and with which they share a common language and colonial ties." ${ }^{36}$ One of the greatest examples of massive donations, however, relates to the responses to the 2004 Indian Ocean tsunami, where the emotional argument was supported by the immediate availability of dramatic images, the fact that the places affected were often touristic destinations, and the disappearance of many European tourists among the victims. ${ }^{67}$

Secondly, the forced migration normative enterprise follows an approach similar to the humanitarian dichotomy between the saviour and those in need of being saved, but it also builds on deep-rooted emotional attachment to the place as an element of identity. It opposes "our" space, seen as a safe haven and a potential place of asylum, to "their" space as inherently troublous. Psychological works on identity building have amply reflected on the role of place in individual identity building - in particular "home," conceived either as "a fortress to be defended" (against invaders) or as "an expression of the self" (to the other); ${ }^{68}$ and the social dynamic at work here seems to build on the same element. Because of the importance given to the place, the forced migration argument is successful mainly in the West when it deals with immigration from the Third World: environmental migrants are conceived as destitute individuals fleeing collapsing socio-environmental systems 
and heading toward "our" sanctuary. On the other hand, the narrative does not apply successfully to South-South or North-North migration: the former is frequently overlooked, ${ }^{69}$ whereas the latter tends to be framed in humanitarian rather than migratory terms. George W. Bush offered an excellent illustration to the geographical rootedness of this argument when he argued that the New Orleanians displaced at the time of hurricane Katrina were not "refugees" but "Americans" who "need[ed] the help and love and compassion of our fellow citizens."70 Because displacement was happening within "our" space, Bush felt an urge to reframe the issue in terms of humanitarian assistance rather than forced migration.

Thirdly, the environmentalist enterprise grounds its argument in a dichotomy between the "wrongdoers" and the "victims." Except for a few instances related to the environmental impact of development projects, ${ }^{71}$ the discourse applies mainly to issues of climate justice. Environmental or climate migrants are conceived as passive individuals, "forced ... to leave their villages and cities to seek refuge in other areas."72 Here, however, the link between "us" and "them" is stronger as the plight of the environmental migrants is attributed to the Western way of life (and sometimes to its imposition on emerging economies). Yet "climate migrants" remain fundamentally the figure of the other in an asymmetrically globalized world. In much of the environmentalist literature, "climate migrants" are described as faceless numbers, generally a number of millions. Jacobson, a pioneer of this approach, argued in 1988 that "the rising number of environmental refugees is the best available measure of changes in the Earth's physical conditions."73 Thus, the environmentalist enterprise deals with "climate refugees" as a symptom-the "canary in the coalmine"-and their numbers as a measure: "climate refugees" are a concern only inasmuch as their plight preludes and announces ours. ${ }^{74}$ Yet, despite their reification and their passiveness, "climate refugees" may also be a threat: the holders of large claims against the Western world, unified by solid moral arguments-a sword of Damocles hanging over "us." Already, developing countries have started rising up and claiming that developed states have to "recognize and commit to honor their climate debt in all its dimensions, ... including through ... being accountable for the hundreds of millions of people that will have to migrate as a result of climate change and to remove their restrictive policies on migration." 75

Lastly, the normative enterprise on international security reverses the roles: it construes "environmental refugees" as a threat. Accordingly, it is because "they" are poor and desperate individuals that "they" are also dangerous; it is because "we" are developed and open societies that we are vulnerable to them. The causes of migration do not matter as much as the growing numbers of increasingly desperate "climate Barbarians at the gates."76 The argument is deeprooted in a latency of xenophobia and racialization. ${ }^{77} \mathrm{In}$ contrast with the environmentalist argument, the security enterprise submits that environmental migrants are so dangerous that defending ourselves against the "victimsturned-villains"78 has become a necessary step.

\section{The Individual Prospects of Four Collective Norm Entrepreneurs}

Which normative enterprise is most likely to succeed? This section assesses the prospects of each enterprise. It identifies extrinsic factors ${ }^{79}$ such as the credibility of collective norm entrepreneurs, the possible emotional engagement of the interlocutors, and the role that domestic and international institutions can play in facilitating the discourse. It also discusses intrinsic elements such as the comprehensibility of the message and its capacity to fit within dominant representations.

\section{Humanitarian Assistance}

The first argument relies on what Fassin called "moral sentiments," which he defined as "the motions that direct our attention to the suffering of others and make us want to remedy them." ${ }^{0}$ Such moral sentiments are arguably inherent to human nature and pre-exist any ethical reflection. ${ }^{81}$ Whereas neither ethics nor moral sentiments are able to determine global politics alone, they certainly have an influence. Humanitarian actors have high prestige, from which credibility ensues.

Yet humanitarianism has also been challenged. Some have highlighted the danger of reifying the beneficiaries of international aid. Thus, for Fassin, "the very gesture that appears to grant them recognition reduces them to what they are not-and often refuse to be-by reifying their condition of victimhood while ignoring their history and muting their words." 82 Others have highlighted the insufficiencies of humanitarianism. In particular, David Rieff reflects a widespread sentiment that "no century has had better norms and worse realities." 83 He argues that, through humanitarianism, "the modern conscience is ... allowed to delegate its guilt and its anxiety to the designated consciences of the world of relief, development and human rights." 84

Humanitarianism surely is not a panacea. It might be best conceived as a cosmetic treatment rather than a substantive cure of the world's ills. Whereas acute humanitarian crises may trigger the commitment of substantial resources, Rudi Muhammad Rizki, the former UN independent expert on human rights and international solidarity, identified "a large gap between assertions of international solidarity in 
theory and their reflection in practice." He added, "The fact that more than 1 billion people suffer from poverty and hunger is an indicator that, as the human race, we are failing to live as one family." 85

So far, humanitarian advocates have been able to gather large funds to respond to a natural disaster, but they have been less successful in triggering resources for long-term policies. The success of normative arguments has been circumscribed to a clarification of state obligations vis-à-vis their own populations and to some technical discussions relating in particular to the right of a state to intervene in another state. ${ }^{86}$ Yet there is little prospect for a broader normative framework, such as one defining state obligations toward the populations of other states. The humanitarian argument is simple, clear, and based on sound ethics, but it is too broad and not be sufficiently specific to have a substantial impact. A full realization of the humanitarian argument would require structural changes for which we might not yet be ready.

\section{Forced Migration}

Whereas the humanitarian argument is in a sense "too big to succeed," the second argument focuses on forms of vulnerability specifically linked to forced displacement. The refugee regime provides these norm entrepreneurs with an essential organizational platform: the UNHCR. Although it does not have a specific mandate for protection, the IOM has also been involved in some research and advocacy. Both international organizations are recognized as strong moral authorities.

The refugee regime is also a common lifeworld upon which norm entrepreneurs have often tried to elaborate their argument. They have done so generally either through an explicit analogy through the notion of "environmental refugees," or through proposals for "stretching" the refugee regime to other forms of "survival migration." ${ }^{7}$ However, the influence of the protection of refugees extends well beyond explicit analogies. Crawford argues that previous ideas may affect later ones in at least three other ways: "as the background discourse; as the organizing principle of institutions and social structures; and through their association with feelings." ${ }^{88}$ Even when not explicitly compared, "environmental migrants" are usually conceived on the background of the international refugee regime: this may explain the extraordinary resistance to ideas of multi-causality (persecution being conceived as a unique and direct drive for displacement), but also the constant emphasis on international migrants. ${ }^{89}$

However, a hurdle to the analogy (be it implicit or explicit) stems from challenges to the international refugee protection. State practice increasingly deviates from the norm, and some of the states most affected by climate change are not parties to the 1951 Convention relating to the Status of Refugees. ${ }^{90}$ In this context, UN High Commissioner for Refugees António Guterres and the UNHCR warn that redefining environmental migrants as "refugees" "could undermine the international protection regime." 91 If this might follow sound political grounds, the position is not necessarily ethically sound: supposing that refugees and "environmental migrants" are in a similar situation and that the amount of generosity is fixed, there is no reason to concentrate all these resources to the sole refugees.

The limit of the rational argument is where the emotional argument develops. There is no essential reason why the migrants should be protected rather than other vulnerable people-and the skeptical school has shown that those most vulnerable were often unable to move for lack of resources. ${ }^{92}$ Yet, among other forms of human sufferings, migration attracts a specific attention that is linked to a deep-rooted fear of invaders. Hathaway demonstrated that the institutionalization of the refugee regime was triggered by "neither a humanitarian nor a human rights vision," but rather by "the pursuit by states of their own well-being"an attempt at "govern[ing] disruptions of regulated international migration in accordance with the interests of states." 93 Yet if regulating international peace and security is the main motivation of critical states, forced migration norm entrepreneurs are opposed to the securitization of the issue: they assume that the outcome of securitization would not benefit forced migrants. As Castles notes, an alarmist discourse would "tend to reinforce existing negative images of refugees as a threat to the security, prosperity and public health of rich countries in the global North." 94

On the other hand, however, there is little prospect for a "skeptical" discourse that would build on complex causality, recognize the rarity of international migration, submit that "migration" is perfectly "normal" and does not "endanger" Western states, and pay attention to those who are unable to move because they lack the resources necessary to move. In terms of communication, such a message would presumably remain perfectly inaudible for most of its interlocutors, not only because of its complexity and lack of emotional roots, but also because it situates the link environmentmigration outside of our lifeworld when, for instance, evading the dichotomy between forced and voluntary migration or when calling for holistic development policies. Such a message would lead to a situation where, as Crawford puts it, "the words may be heard, but because of their different Weltanshung [Weltanschauung], interlocutors find they are incomprehensible to each other. Thus, those with power will not hear or even consciously exclude those who do not speak in the terms of the dominant discourse." 95 
Stuck in a dilemma between an alarmist narrative that risks being diverted by security actors and a feeble discourse that does not fit into the dominant lifeworld, forced migration advocates have had a hard time finding their place in the environmental migration debate. As a result, they have often developed a halfway, "neither-nor" approach, denouncing the notion of "environmental migration" in introductory considerations yet immediately leaving these remarks aside. ${ }^{96}$ Nicholson identified this "ontological contradiction" in the academic literature: "There will be an acknowledgement that the 'drivers' of migration are always complex, and that all migration is conditioned by myriad contingencies and 'geo-social-political context.' Yet the same authors will often then continue to refer to 'climate displacement' as if it were an essential category." 97 In terms of protection, the concept of "environmental migration" is both impractical and irrelevant. Yet the advocates of forced migration could not but attempt to use the environmental migration debate to pursue further goals.

\section{Environmental Sustainability}

At first sight, the environmentalist normative enterprise appears quite promising. The call for adapting international governance to a new issue and the framing of this issue as a matter of responsibility touch deep-rooted, largely shared ethical principles. There is a strong scientific argument: experts overwhelmingly agree on the reality of global, anthropogenic climate change. ${ }^{98}$ Besides, there are strong institutions. The 1992 UN Framework Convention on Climate Change, with 195 parties, is one of the most widely ratified treaties. The issue attracts great attention globally, as the large "COPs" (Conferences of the Parties) gather tens of thousands of environmental activists and journalists each year. Responsibility is also recognized in international law, at least when a state is responsible for the "serious consequences" that its conduct could cause to other states. ${ }^{99}$ Attaching "environmental migration" to climate change might therefore look like a powerful argumentative strategy.

Yet there are four significant obstacles to the success of this argument. Firstly, the application of the argument is inconsistent with its ethical basis. Responsibility for climate change pleads for "compensation"-unconditional financial flows from those states "responsible" for climate change and those "affected" by it. This is roughly the approach followed by negotiations on loss and damages. Yet a corrective justice argument does not seem able to justify a centralized governance of climate migration, which would further curtail the sovereignty of the "injured" states. Responsibility does not justify interference.
Secondly, studies in the sociology of media on climate change show a tendency to over-represent skeptical claims over more serious scientific arguments, for the sake of what Boykoff and Boykoff call "adherence to first-order journalistic norms-personalization, dramatization, and novelty."100 In another article, the same authors recall that industrial lobbies may also play a role in favouring skeptical claims to avoid costly mitigation measures, thus struggling against the scientific basis of the argument. ${ }^{101}$ These factors explain that climate change denial remains influential, in particular in American media, despite the absence of any scientific support.

Thirdly, other authors have identified a gap between a cold scientific argument and its emotional perceptionwhat Collins and Evans called "science's ... short-term political impotence."102 Thus, Leiserowitz showed that, "while large majorities of Americans believe climate change is real and consider it a serious problem, it remains a low priority relative to other national and environmental issues": it "lacks a sense of urgency." 103 Leiserowitz and other psychologists explain that this is due to a gap in perception: whereas climate change-related risks are viewed as affecting mostly "people and places far distant in space and time," the costs of potential response policies are immediately tangible. ${ }^{104}$ In this context, individuals are tempted to "erect barriers to their personal commitment" to the issue, despite-or because - of their anxiety. ${ }^{105}$ Too much of an alarmist discourse could thus favour policies that do not aim at avoiding, but rather at protecting ourselves against, climate changeinduced migration-thus benefitting the fourth collective norm entrepreneurs.

Fourthly, although the ethical bases of the argument are relatively simple, environmental advocates fail to prescribe any simple solution. According to Williams, the absence of simple and efficient "packageable solutions" impedes the success of the scientific argument. ${ }^{106}$ Furthermore, Hulme is concerned that "climate change is not making sense to us." 107 Hulme denounces the domination of a "purely physical reading of climate change" 108 that strips the discourse from "their constitutive human values and cultural meanings." 109 As a consequence, he argues, "climate change becomes a malleable envoy enlisted in support of too many rulers." ${ }^{110}$ In a commentary on a proposal for a "climate refugee" convention, Hulme similarly expressed concerns over delegating "the fate of millions" to "some distant UN committee" that would oversee the "social dynamic of change in which multiple values and power relations are at work."111 If the protection of environmental migrants is really what environmentalists strive for, they will need to coalesce with forced migration pundits and take the skeptical approach into account; if they strive for raising awareness on the need 
for greater environmental sustainability, the argument will suffer from their inability to propose a simple solution.

\section{International Security}

The foundations of the last argument are often denigrated by researchers ${ }^{112}$ with few exceptions. According to Elliott, for instance, "Claims about climate and environmental security, and about the security implications of climate migration, are ... both empirically and conceptually fraught." 113 Despite this reception in the academic world, a larger audience often perceives security experts as credible norm entrepreneurs. The successful securitization of environmental migration reflects strong inequalities in the formation of public discourse. If it describes securitization as an "act of speech," the Copenhagen school of security studies also shows that the "securitizing agents" must also secure an argument that would "achieve sufficient effect to make an audience tolerate violations of rules that would otherwise have to be obeyed." 114 The way environmental migration has been securitized reflects a strong ascendency of Western norm entrepreneurs in the construction of environmental migration. The notion of a human security, as an attempt at displacing the emphasis from the receiving states to environmental migrants, ${ }^{115}$ has had only a very little influence.

Security pundits possess strong institutional support, in particular from interested industrial lobbies, and they have had access to critical organizational platforms, including the United Nations Security Council. ${ }^{116}$ Above all, they were able to deploy what the three other collective norm entrepreneurs lack: an efficient message. As White puts it, "Thinking in security terms is relatively easy." 117

The security argument is rooted in strong emotionsfears - that compel immediate action. Here, the grounds for fear are diverse. A first layer of fears is xenophobic, sometimes racist; it relates to a "flood" of immigrants who would steal "our" jobs, confuse "our" national identity, or even perhaps bring violence or mix with "our" "race." This message is particularly efficient in the post-9/11 lifeworld, where migration is constantly associated with threats. Yet a second layer of fears relates to the touch of newness and uncertainty that "climate change" brings. Uncertainty and fears call for early precautionary measures.

Moreover, unlike the three other collective norm entrepreneurs, security norm entrepreneurs prescribe a solution that can be perceived as simple, realistic, and efficient. "Building fences against irregular migration is politically successful,"118 White notes. It certainly is more politically successful than funding humanitarian cooperation or climate change adaptation. Here again, the security discourse does not need epistemological accuracy to persuade key actors (governments and their constituencies) that derogations are justified in the face of migration and that military spending must be increased. This success is in spite of the gap, that Elliott highlights, between the "image of processes that are likely to be out of control and therefore highly threatening" in the security literature and empirical evidence that "slowinduced migration is the more likely outcome in the context of climate change."119 The international security enterprise is misleading, ${ }^{120}$ but, in terms of communication, it is also a particularly powerful argument that multiplies the fears of migration by the uncertainties of climate change.

\section{The Prospects of a Disputed Issue}

This article is a first attempt at applying constructivist theories to the normative debate on environmental migration. It identifies one methodological difficulty: the existence of four distinct collective norm entrepreneurs, for whom environmental migration is only an intermediary step toward different ultimate goals. The existing theoretical frame focuses on norm entrepreneurship by either a unique actor, ${ }^{121}$ or a set of actors sharing a unique goal, ${ }^{122}$ who combat inert bureaucracies, all things being equal. Here, however, applying these theories prospectively to the issue of environmental migration shows that different norm entrepreneurs concurrently frame environmental migration as an issue: they speak to the interlocutors with similar words, but their messages differ.

These norm entrepreneurs cannot but interact with one another. This is not only because normative enterprises generally struggle for public attention in what may appear as a finite pool of worries, ${ }^{123}$ but all the more because, with regard to environmental migration, they compete on the same conceptual grounds. The reception of a message depends on its understanding by the interlocutor, which is framed partly by the previous reception of other messages. The four collective norm entrepreneurs identified here write different stories, but on the same support, with the risk that the audience may amalgamate all four narratives into a somewhat confused understanding.

The prospects of a dispute issue can be analyzed only in relation to other such enterprises. The following remarks are a sketch for more thorough analyses of such complex interactions. Four conclusions can be suggested.

Firstly, as to the representation of environmental migration, the maximalist (environmentalist and security) and minimalist (humanitarian and forced migration) enterprises are in direct epistemological contradiction: neither of them can fully succeed unless it eliminates the other. The rational argument, backed by a host of empirical studies showing the complex linkages between environmental factors and migration, is obviously on the side of the skeptical 
perspective. However, the alarmist representation constitutes a simpler, more efficient message. Therefore, at least in the short term, the alarmist representation seems likely to maintain its ascendency in the political representations. ${ }^{124}$

Secondly, as to the nature of the argument, two approaches clash. For the humanitarian, forced migration, and environmentalist norm entrepreneurs, the disputed issue of environmental migration is before all an ethical one. For the security norm entrepreneurs, however, it is a question of self-protection. These approaches are not necessarily incompatible, but there is a finite space available in the public discourse, and one argument often takes attention away from the other. The two approaches call to different emotions, respectively empathy and fears: once an audience has associated environmental migration with existential fears, it is doubtful that it may return to empathy. Because fear is a more urgent feeling, security norm entrepreneurs are likely to impose a self-protective approach over the ethical one. The securitization of environmental migration may significantly impede ethical arguments because the discourse of animosity will interfere with the discourse of solidarity: the necessity of protecting "us" situates the debate beyond the realm of ethics: it outshines the desire to help "them."

Thirdly, as to the scope of the argument, it might be assumed that actors will prefer an argument prescribing a solution perceived as cheaper, at least if the outcomes are perceived as similar. To that extent, the forced migration argument has an advantage over the broader humanitarian argument: it is more specific and focuses on the most visible part-the displaced. In other words, addressing forced migration has a better satisfaction-to-cost ratio: it gives us a better image of ourselves at a lesser price. This advantage, however, is not an absolute one. By denouncing "invisibility" and highlighting the "roots of the problem" (of displacement), humanitarian advocates may successfully call for some attention to those "trapped in place." Their position will, however, remain subordinate to the forced migration argument, as it follows from the very structure of their argument-a comparison between visible migrants and invisible non-migrants.

Fourthly, as to the capacity of each normative enterprise to prescribe a solution perceived as simple and efficient, the security argument certainly prevails over each of the other arguments. The humanitarian, forced migration, and environmentalist solutions are plagued by aid fatigue and more generally by the limits of our willingness to "give," especially against a background of endless economic crises. It also suffers from the difficulties of engaging in global cooperation, and, in the absence of such cooperation, from the feeling that the aid brought by one isolated state would be a drop in the ocean of needs. In comparison, the solutions prescribed by security norm entrepreneurs are (wrongly) perceived as efficient and cheap. As a matter of fact, it is profoundly disturbing to consider that the security argument might benefit from the social dynamics raised by other norm entrepreneurs. The increasing denunciation for environmental migration as a humanitarian, migration, and climate-change crisis might thus end up reinforcing the security narrative, leading to a further securitization of migration and climate change, and harming the climate migrants more than anyone else. This diversion of social awareness is more likely when arguments are based on, or influenced by, a similar alarmist representation of environmental migration.

Ultimately, the international security collective norm entrepreneur is likely to play the greatest role in defining possible solutions to environmental migration. Research and advocacy may continue to focus on other arguments, and these arguments might inflect policies, but the humanitarian, forced migration, and environmental arguments will not, on their own, define the global governance of environmental migration: they will remain subordinated to logics of fears and to their capacity to relate to the dominant discourse.

\section{Conclusion}

Wendt warned that, "if anything, structural change should be quite difficult." ${ }^{25}$ Four normative enterprises competing on the same conceptual field do not make things any easier. If some change is certainly happening, ${ }^{126}$ it is unlikely that the fundamental limits to the governance of humanitarian assistance, forced migration, or environmental sustainability will change as a result of the debate on environmental migration. In a world where migration is increasingly perceived as a threat to national security rather than an incredible opportunity for development and transcultural intercourse, the cold analysis initiated in this article suggests that the security argument for the "management" of environmental migration is most likely to succeed. With the aid of scholars, the advocates of humanitarian assistance, forced migration and environmental sustainability should reframe their argument in a language compatible with the security discourse, perhaps through concepts such as "human security" or, more convincingly, "global interdependence."

\section{Acknowledgment}

I am thankful to Simon Chesterman and to two anonymous reviewers for helpful comments, and to Cef Valderrama for proof-reading. 


\section{Notes}

1. See, e.g., Frank Biermann and Ingrid Boas, "Protecting Climate Refugees: The Case for a Global Protocol," Environment: Science and Policy for Sustainable Development 50 (2008): 8; Bonnie Docherty and Tyler Giannini, "Confronting a Rising Tide: A Proposal for a Convention on Climate Change Refugees," Harvard Environmental Law Review 33 (2009): 349; Emma Brindal, "Asia Pacific: Justice for Climate Refugees," Alberta Law Review 32 (2007): 240; Angela Williams, "Turning the Tide: Recognizing Climate Change Refugees in International Law, Law \& Policy 30 (2008): 502; Derek R. Bell, "Environmental Refugees: What Rights? Which Duties?”, Res Publica 10 (2004): 135; Norman Myers, "Environmental Refugees: A Growing Phenomenon of the 21st Century," Philosophical Transactions of the Royal Society: Biological Sciences 357 (2002): 609; Myers, "Environmental Refugees in a Globally Warmed World," BioScience 43 (1993): 752; Laura Westra, Environmental Justice and the Rights of Ecological Refugees (London: Earthscan, 2009); Christel Cournil, "The Protection of 'Environmental Refugees' in International Law," in Migration and Climate Change, ed. Etienne Piguet, Antoine Pécoud, and Paul de Guchteneire (Paris: UNESCO, 2011), 359; Harry Wijnberg and Stuart M. Leiderman, "The Toledo Initiative on Environmental Refugees and Ecological Restoration" (2004), http://www.reseau-terra.eu/ IMG/doc/Toledo_Initiative.doc.

2. E.g., CARE, Equity BD, Christian Aid, Bread for the World, World Council of Churches, etc.

3. See, for example, Essame El-Hinnawi, Environmental Refugees (Nairobi: United Nations Environmental Program, 1985); "Climate Change and Its Possible Security Implications: Report of the Secretary-General," U.N. Doc. A/64/350 (2009); IOM, UNHCR, UNU, Norwegian Refugee Council, Representative of the Secretary-General on the Human Rights of Internally Displaced Persons, Climate Change, Migration, and Displacement: Impacts, Vulnerability, and Adaptation Options, submission to the AWG-LCA 5 (2009); Antonio Guterres, Climate Change, Natural Disasters and Human Displacement: A UNHCR Perspective (Geneva: UNHCR, 2009); IOM, Environment, Climate Change and Migration: IOM's Approach and Activities (Geneva: IOM, 2011); IOM, Disaster Risk Reduction and Climate Change Adaptation in IOM's Response to Environmental Migration (Geneva: IOM, 2011); IOM, Climate Change, Environmental Degradation and Migration: Addressing Vulnerabilities and Harnessing Opportunities (Geneva: IOM, 2009); Asian Development Bank, Facing the Challenge of Environmental Migration in Asia and the Pacific (Manila: ADB, 2011); Report of the Special Rapporteur on the Human Rights of Migrants, U.N. Doc. A/67/299 (2012).

4. Many states considered as affected by climate migration have been vocal in calling for international responses. More recently, some critical states have come to the fore, pleading for an international action. See, in particular, on the Nansen Initiative, Walter Kälin, "From the Nansen Principles to the Nansen Initiative," Forced Migration 41 (2012): 48

5. This saying is often attributed to Antoine de Saint-Exupéry, although I could not find the original source.

6. Jeffrey T. Checkel, "The Constructivist Turn in International Relations Theory," World Politics 50 (1998): 325.

7. See Jacques Derrida, De la Grammatologie (Paris: Éditions de Minuit, 1967). See also Maja Zehfuss, Constructivism in International Relations: The Politics of Reality (Cambridge: Cambridge University Press, 2002), 196; Thomas Risse, Stephen C. Ropp, and Kathryn Sikkink, The Power of Human Rights: International Norms and Domestic Change (Cambridge: Cambridge University Press, 1999); Emanuel Adler, "Seizing the Middle Ground: Constructivism in World Politics," European Journal of International Relations 3 (1997): 133.

8. See Martha Finnemore and Kathryn Sikkink, "International Norm Dynamics and Political Change," International Organization 52 (1998): 916; Cass R. Sunstein, "Social Norms and Social Roles," Columbia Law Review 96 (1996): 903; Alexander Wendt, Social Theory of International Politics (Cambridge: Cambridge University Press, 1999).

9. Ian Johnstone, "The Secretary-General as Norm Entrepreneur," in Secretary or General: The UN Secretary-General in World Politics, ed. Simon Chesterman (Cambridge: Cambridge University Press, 2007), 127-8.

10. Finnemore and Sikkink, "International Norm Dynamics," 896.

11. Ibid., 898. Similarly, Koh distinguishes between interaction, interpretation, and internalization. See Harold Hongju Koh, "Why Do Nations Obey International Law?" Yale Law Journal 106 (1997): 2659. Johnstone similarly identifies three stages, respectively, marked by norm creation, institutionalization, and interpretation. Johnstone, "Secretary-General," 127-9.

12. Ibid., 126 .

13. Ibid.

14. Finnemore and Sikkink, "International Norm Dynamics," 899.

15. See, e.g., Margaret E. Keck, Activists beyond Borders: Advocacy Networks in International Politics (Ithaca, NY: Cornell University Press, 1998).

16. See, e.g., Michael Barnett and Martha Finnemore, Rules for the World: International Organizations in Global Politics (Ithaca, NY: Cornell University Press, 2004).

17. See, e.g., Annika Björkdahl, "Norm Advocacy: A Small State Strategy to Influence the EU," Journal of European Public Policy 15 (2008): 135.

18. Respectively: ibid. (state); Michelle Pace, "Norm Shifting from EMP to ENP: The EU as a Norm Entrepreneur in the South?", Cambridge Review of International Affairs 20 (2007): 659 (EU); Barnett and Finnemore, Rules for the World, 17 (international organization). 
19. Their project is more far-reaching and aims at replacing arguments at the core of the analysis of international relations. Crawford submits that "an understanding of the world politics that minimizes the role of talk and argument has been deeply misleading and at the same time it serves the interests of those who do not want to have to defend, with arguments, their views and the arrangement of power they favor." Neta C. Crawford, "Homo Politicus and Argument (Nearly) All the Way Down: Persuasion in Politics," Perspectives on Politics 7 (2009): 120. The project is thus one of opening an explicit and perhaps transformative dialogue on the creation of norms.

20. Thomas Risse, "Global Governance and Communicative Action," Government and Opposition 29 (2004): 288. On the origin of the "logical of appropriateness," see James G. March and Johan P. Olsen, "The Institutional Dynamics of International Political Orders," International Organization 52 (1998): 951.

21. Neta C. Crawford, Argument and Change in World Politics: Ethics, Decolonization, and Humanitarian Intervention (Cambridge: Cambridge University Press, 2002), 14.

22. Crawford, "Homo Politicus," 106 (emphasis omitted).

23. See Simone Chambers, Reasonable Democracy: Jürgen Habermas and the Politics of Discourse (Ithaca, NY: Cornell University Press, 1996), 155.

24. Thomas Risse, "Let's Argue!': Communicative Action in World Politics," International Organization 54 (2000): 8-9.

25. Crawford, "Homo Politicus," 107 (emphasis in original).

26. Anthony Leiserowitz, "Climate Change Risk Perception and Policy Preferences: The Role of Affect, Imagery, and Values," Climatic Change 77 (2006): 47-8.

27. Seymour Epstein, "Integration of the Cognitive and the Psychodynamic Unconscious," American Psychologist 49 (1994): 711.

28. Finnemore and Sikkink, "International Norm Dynamics," 916. See also Neta C. Crawford, "The Passion of World Politics: Propositions on Emotion and Emotional Relationships," International Security 24 (2000): 116.

29. Crawford, "Homo Politicus," 107.

30. Ibid., 105.

31. Ibid., 106 .

32. Ibid., 106-7.

33. Ibid., 106.

34. Ibid., 110. See also Risse, “'Let's Argue!”' 12, 14.

35. Crawford, "Homo Politicus," 110.

36. Ibid.

37. Finnemore and Sikkink, "International Norm Dynamics," 906.

38. Ibid., 907.

39. Crawford, "Homo Politicus," 118.

40. Finnemore and Sikkink, "International Norm Dynamics," 907, and references cited.

41. Risse, “'Let's Argue!"” 33.

42. Finnemore and Sikkink, "International Norm Dynamics," 899, 900.
43. François Gemenne, "How They Became the Human Face of Climate Change: Research and Policy Interactions in the Birth of the 'Environmental Migration' Concept," in Piguet, Pécoud, and de Guchteneire, Migration and Climate Change, 225; James Morrissey, Environmental Change and Forced Migration: A State of the Art Review (Oxford: Refugee Studies Center, Oxford Department of International Development, 2009); Cord Jakobeit and Chris Methmann, "Climate Refugees' as Dawning Catastrophe? A Critique of the Dominant Quest for Numbers," in Climate Change, Human Security and Violent Conflict, ed. Jürgen Scheffran, Michael Brzoska, Hans Günter Brauch, Peter Michael Link, and Janpeter Schilling (Heidelberg: Springer, 2012) 301.

44. Jodi L. Jacobson, Environmental Refugees: A Yardstick of Habitability (Washington, DC: Worldwatch Institute, 1988); El-Hinnawi, Environmental Refugees; Myers, "Environmental Refugees"; Diane C. Bates, "Environmental Refugees? Classifying Human Migrations Caused by Environmental Change," Population \& Environment 23 (2002): 465; Christian Aid, Human Tide: The Real Migration Crisis (London: Christian Aid, 2007); Biermann and Boas, "Protecting Climate Refugees"; WBGU, Climate Change as a Security Risk (Berlin: German Advisory Council on Global Change / Earthscan, 2008); Gregory S. McCue, "Environmental Refugees: Applying International Environmental Law to Involuntary Migration," Georgetown International Environmental Law Review 6 (1993): 151.

45. Foresight, Migration and Global Environmental Change: Final Project Report (London: Government Office for Science, UK, 2011), 9; Gaim Kibreab, "Migration, Environment and Refugeehood," in Environment and Population Change, ed. B. Zaba and J. Clarke (Liège, Belgium: International Union for the Scientific Study of Population, 1994), 115; Kibreab, "Environmental Causes and Impact of Refugee Movements: A Critique of the Current Debate," Disasters 21 (1997): 20; Richard Black, Refugees, Environment and Development (Harlow, UK: Longman, 1998); Black, "Environmental Refugees: Myth or Reality?, UNHCR Working Paper on New Issues in Refugee Research no. 34 (Geneva: UNHCR, 2001); Richard Black, Dominic Kniveton, Ronald Skeldon, Daniel Coppard, Akira Murata, and Kerstin Schmidt-Verkerk, "Demographics and Climate Change: Future Trends and Their Policy Implications for Migration," Migration DRC Working Paper T-27 (Brighton, UK: University of Sussex, 2008); Astri Suhrke and A. Visenting, "The Environmental Refugee: A New Approach," Ecodecision 2 (1991): 73; Astri Suhrke, "Environmental Degradation and Population Flows," Journal of International Affairs 47 (1994): 473; Stephen Castles, "Environmental Change and Forced Migration: Making Sense of the Debate," UNHCR Working Paper on New Issues in Refugee Research no. 70 (Geneva: UNHCR, 2002); Graeme Hugo, Migration, Development and Environment (Geneva: IOM, 2008); Hugo, "Future Demographic Change and Its 
Interactions with Migration and Climate Change," Global Environmental Change 21 (2011): S21.

46. See Carol Farbotko and Heather Lazrus, "The First Climate Refugees? Contesting Global Narratives of Climate Change in Tuvalu," Global Environmental Change 22 (2012): 382; Benoit Mayer, "Constructing Climate Migration as a Global Governance Issue: Essential Flaws in the Contemporary Literature," McGill Journal of Sustainable Development Law and Policy 9 (2013): 87. For some of the most authoritative empirical studies, see, e.g., Foresight, Migration and Global Environmental Change; EACH-FOR, Synthesis Report (EACH-FOR, 2009); United Nations University, Where the Rain Falls: Global Policy Report (Bonn: UNU, 2012).

47. See, e.g., Gemenne, "How They Became the Human Face," 44.

48. Chloe Vlassopoulou, "Institutional Barriers to the Recognition and Assistance of Environmentally Forced Migrants," in Environment, Forced Migration and Social Vulnerability, ed. Tamer Afifi and Jill Jäger (Berlin: Springer, 2010), 24.

49. United Nations Development Programme, Human Development Report 2007/2008: Fighting Climate Change; Human Solidarity in a Divided World (New York: United Nations Development Programme, Palgrave Macmillan, 2007).

50. Asian Development Bank, Addressing Climate Change and Migration in Asia and the Pacific (Manila: ADB, 2012).

51. United Nations University, Where the Rain Falls; Christian Aid, Human Tide.

52. Pierre Minn, "Toward an Anthropology of Humanitarianism," Journal of Humanitarian Assistance 6 (2007), https:// sites.tufts.edu/jha/archives/51

53. Environmental Justice Foundation, A Nation under Threat (London: EJF, 2012).

54. CNA Corporation, National Security and the Threat of Climate Change (Alexandria, VA: CNA, 2007); Jane's Information Group, "Hostile Environment: Climate Change and Resources Stress Threaten Global Stability," Jane's Defence Weekly 46, no. 16 (2009): 24.

55. UN Security Council, "Debate on the Impact of Climate Change," SC/9000 (New York: Department of Public Information, 2007). See also UN Secretary General, Climate Change and Its Possible Security Implications: Report of the Secretary-General, U.N. Doc. A/64/350 (2009).

56. D. Smith and J. Vivekananda, "A Climate of Conflict: The Links between Climate Change, Peace and War" (London: International Altert, 2007); Kurt M. Campbell, Jay Gulledge, J. R. McNeill, John Podesta, Peter Ogden, leon Fuerth, R. James Woolsey, Alexander T. J. lennon, Julianne Smith, Richard Weitz, and Derek Mix, The Age of Consequences: The Foreign Policy and National Security Implications of Global Climate Change (Washington: Centre for Strategic and International Studies, 2007); A. Dupont, "The Strategic Implications of Climate Change," Survival: Global Politics and Strategy 50, no. 3 (2008): 29; Jason D.
Söderblom, "Climate Change: National \& Regional Security Threat Multiplier for Australia," Security Solutions 52 (2008): 58

57. See, e.g., Benoit Mayer, Ingrid Boas, Jackson Ewing, Alice Baillat, and Uttam Kumar Das, "Governing Environmentally-Related Migration in Bangladesh: Responsibilities, Security, and the Causality Problem," Asian and Pacific Migration Journal 22 (2013): 177.

58. See, in particular, Betsy Hartmann, "Rethinking Climate Refugees and Climate Conflict: Rhetoric, Reality and the Politics of Policy Discourse," Journal of International Development 22 (2010): 233

59. See Benoit Mayer, "Environmental Migration in the AsiaPacific Region: Could We Hang Out Sometime?", Asian Journal of International Law 3 (2013): 101. See also Jane McAdam and Maryanne Loughry, "We aren't refugees," Inside Story: Current Affairs and Culture from Australia and Beyond (30 June 2009), http://inside.org.au/ we-arent-refugees/.

60. See Fanny Florémont, "Migratory Issues in Climate Adaptation Policies: A New Conceptualisation of Population Displacements?", Foreign Development Studies 39 (2012): 31 (showing that the politicisation of environmental migration in Mali is mostly donor driven: internal migrants are not influential in promoting norms for their own benefit).

61. Crawford, "Homo Politicus," 118.

62. See, for instance, Foresight, Migration and Global Environmental Change.

63. Foresight, Migration and Global Environmental Change: Final Project Report, 9.

64. Chimni recalls rightly that "Forced Migration Studies always seeks to signify the Other." See B.S. Chimni, "The Birth of a 'Discipline': From Refugee to Forced Migration Studies," Journal of Refugee Studies 22 (2009): 20.

65. On the role of identity-building in constructivist theories, see Wendt, Social Theory, 140.

66. David Strömberg, "Natural Disasters, Economic Development, and Humanitarian Aid," Journal of Economic Perspectives 21 (2007): 221.

67. Jock Stirrat, "Competitive Humanitarianism: Relief and the Tsunami in Sri Lanka," Anthropology Today 22 (2006): 13.

68. Claire Christine Cooper, "The House as Symbol of Self," in Designing for Human Behavior: Architecture and the Behavioral Sciences, ed. Jon T. Lang (Stroudsburg, PA: Dowden, Hutchinson \& Ross, 1974), 130. See also Kenneth O. Doyle, "The Symbolic Meaning of House and Home: An Exploration in the Psychology of Goods," American Behavioral Scientist 35 (1992): 790; Kenny Chow and Mick Healey, "Place Attachment and Place Identity: First-Year Undergraduates Making the Transition from Home to University," Journal of Environmental Psychology 28 (2008): 362; Richard C. Stedman, "Toward a Social Psychology of Place Predicting Behavior from Place-Based Cognitions, Attitude, and Identity, Environment and Behavior 34 (2002): 561; Mindy Thompson Fullilove, "Psychiatric Implications 
of Displacement: Contributions from the Psychology of Place," American Journal of Psychiatry 153 (1996): 1516.

69. See, in particular, Khalid Koser, "Climate Change and Internal Displacement: Challenges to the Normative Framework," in Piguet, Pécoud, and de Guchteneire, Migration and Climate Change, 289.

70. White House, "President Meets with Representatives from National Voluntary Organizations," cited in François Gemenne, "What's in a Name: Social Vulnerabilities and the Refugee Controversy in the Wake of Hurricane Katrina," in Afifi and Jäger, Environment, Forced Migration and Social Vulnerability, 37.

71. For an example of a responsibility narrative on non-climate-related environmental migration, see Gil Marvel Tabucanon and Brian Opeskin, "The Resettlement of Nauruans in Australia: An Early Case of Failed Environmental Migration," Journal of Pacific History 46 (2011): 337.

72. Biermann and Boas, "Protecting Climate Refugees," 61.

73. Jodi L. Jacobson, "Environmental Refugees: A Yardstick of Habitability," Bulletin of Science, Technology \& Society 8 (1988): 257.

74. See, e.g., Farbotko and Lazrus, "The First Climate Refugees?", 385.

75. Bolivia (submission received 26 April 2010), in Additional Views on Which the Chair May Draw in Preparing Text to Facilitate Negotiations among Parties: Submission from Parties, 30 April 2012, UNFCCC Doc. FCCC/AWGLCA/2010/ MISC.2, 17.

76. Giovanni Bettini, "Climate Barbarians at the Gate? A Critique of Apocalyptic Narratives on 'Climate Refugees," Geoforum 45 (2013): 63.

77. "Environmental refugees" are often pictured as darkskinned aliens. On the latency of xenophobia in our perception of migration, see Andrew Baldwin, "Racialisation and the Figure of the Climate-Change Migrant," Environment and Planning: Part A 45 (2013): 1474.

78. Betsy Hartmann, "From Climate Refugees to Climate Conflict: Who Is Taking the Heat for Global Warming?", in Climate Change and Sustainable Development: New Challenges for Poverty Reduction, ed. M. Salih (Cheltenham, UK: Edward Elgar, 2009), 143.

79. On the distinction between extrinsic and intrinsic barriers, see Crawford, "Homo Politicus," 118.

80. Didier Fassin, Humanitarian Reason: A Moral History of the Present (Berkeley: University of California Press, 2011), 1.

81. See, e.g., ibid.

82. Ibid., 254.

83. David Rieff, A Bed for the Night: Humanitarianism in Crisis (New York: Simon \& Schuster, 2003), 70, cited in Minn, "Toward an Anthropology of Humanitarianism."

84. Ibid., 96.

85. Rudi Muhammad Rizki, Report of the Independent Expert on Human Rights and International Solidarity, U.N. Doc. A/ HRC/15/32, 5 July 2010, para. 6, 7.
86. See, in particular, Eduardo Valencia-Ospina, Fifth Report on the Protection of Persons in the Event of Disasters, UN Doc. A/CN.4/652 (2012).

87. Alexander Betts, Survival Migration: Failed Governance and the Crisis of Displacement (Ithaca, NY: Cornell University Press, 2013).

88. Nita Crawford, "How Previous Ideas Affect Later Ideas," in The Oxford Handbook of Contextual Political Analysis, ed. Robert E. Goodin and Charles Tilly (Oxford: Oxford University Press, 2006), 267.

89. See Benoit Mayer, "Pour en finir avec la notion de 'réfugiés environnementaux': Critique d'une approche individualiste et universaliste des déplacements causés par des changements environnementaux," McGill International Journal of Sustainable Development Law and Policy 7 (2011): 33. On the oversight of internal displacements in the literature, see, e.g., Koser, "Climate Change and Internal Displacement," 289.

90. For instance, Bangladesh, India. See Mayer, "Environmental Migration in the Asia-Pacific Region."

91. UNHCR, The State of the World's Refugees: In Search of Solidarity (Oxford: Oxford University Press, 2012), 170.

92. See, e.g., Foresight, Migration and Global Environmental Change.

93. James C. Hathaway, "A Reconsideration of the Underlying Premise of Refugee Law," Harvard International Law Journal 31 (1990): 166.

94. Castles, "Afterword: What Now? Climate-Induced Displacement after Copenhagen," in Climate Change and Displacement: Multidisciplinary Perspectives, ed. Jane McAdam (Oxford: Hart, 2010), 242. See also, on communicating about migration: IOM, World Migration Report (Geneva: IOM, 2011), 3.

95. Crawford, "Homo Politicus," 118.

96. For a discussion of Jane McAdam, Climate Change, Forced Migration, and International Law (Oxford: Oxford University Press, 2012); and Gregory White, Climate Change and Migration: Security and Borders in a Warming World (New York: Oxford University Press, 2011), see Mayer, "Constructing Climate Migration.”

97. Calum T. M. Nicholson, book review, Journal of Refugee Studies 25 (2012): 584 (references omitted).

98. See, for instance, Naomi Oreskes, "The Scientific Consensus on Climate Change," Science 306 (2004): 1686.

99. Trail Smelter arbitration case, (1938/1941) 3 R.I.A.A. 1905 (US v Canada). See also International Law Commission, Draft Articles on Responsibility of States for Internationally Wrongful Acts with commentaries, art. 4, 5, U.N. GAOR, 56th Sess., Supp. No. 10, U.N. Doc. A/56/10 (12 December 2001).

100. Maxwell T. Boykoff and Jules M. Boykoff, "Climate Change and Journalistic Norms: A Case-Study of US Mass-Media Coverage," Geoforum 38 (2007): 1190. 
101. Maxwell T. Boykoff and Jules M. Boykoff, "Balance as Bias: Global Warming and the US Prestige Press," Global Environmental Change 14 (2004): 133.

102. Harry Collins and Robert Evans, Rethinking Expertise (Chicago: University of Chicago Press, 2007), 2.

103. Leiserowitz, "Climate Change Risk Perception," 64. See also Elke U. Weber, "Experience-Based and DescriptionBased Perceptions of Long-Term Risk: Why Global Warming Does Not Scare Us (Yet)," Climatic Change 77, nos. 1-2 (2006): 103.

104. Ibid. See also Janet Swim, Susan Clayton, Thomas Doherty, Robert Gifford, George Howard, Joseph Reser, and Elke Weber, Psychology and Global Climate Change: Addressing a Multi-faceted Phenomenon and Set of Challenges (Washington, DC: American Psychological Association 2010), 6-7.

105. S. Stoll-Kleemann, Tim O'Riordan, and Carlo C. Jaeger, "The Psychology of Denial concerning Climate Mitigation Measures: Evidence from Swiss Focus Groups," Global Environmental Change 11 (2001): 107.

106. J. Williams, "The Phenomenology of Global Warming: The Role of Proposed Solutions as Competitive Factors in the Public Arenas of Discourse," Human Ecology Review 7 (2000): 71.

107. Mike Hulme, "Geographical Work at the Boundaries of Climate Change," Transactions of the Institute of British Geographers 33 (2008): 9.

108. Ibid., 7.

109. Ibid., 8.

110. Ibid., 10.

111. Mike Hulme, Frank Biermann, and Ingrid Boas, "Commentary and Response: Climate Refugees; Cause for a New Agreement?," Environment 50 (2008): 50.

112. See, e.g., Lorraine Elliott, "Climate Migration and Climate Migrants: What Threat, Whose Security?," in McAdam, Climate Change and Displacement, 175; White, Climate Change and Migration; Giovanni Bettini, "(In-)Convenient Convergences: 'Climate Refugees', Apocalyptic Discourses and the Depoliticization of the Debate on Climate-Induced Migration," in (De-)Constructing the Greenhouse: Interpretive Approaches to Global Climate Governance, ed. Chris Methmann, Delf Rothe, and Benjamin Stephan (Berlin: Routledge, 2012), 122.

113. Elliott, "Climate Migration and Climate Migrants," 176.

114. Barry Buzan, Ole Wæver, and Jaap De Wilde, Security: A New Framework for Analysis (Boulder, CO: Lynne Rienner Publishers, 1998), 25. See also Lene Hansen, "The Little Mermaid's Silent Security Dilemma and the Absence of Gender in the Copenhagen School," Millennium: Journal of International Studies 29 (2000): 285.
115. Elliott, "Climate Migration and Climate Migrants."

116. UN Security Council, "Debate on the Impact of Climate Change."

117. White, Climate Change and Migration, 124.

118. Ibid., 88.

119. Lorraine Elliott, "Human Security, Climate Change and Migration in Southeast Asia," in Climate Change, Migration and Human Security in Southeast Asia, ed. Lorraine Elliott (Singapore: S. Rajaratnam School of International Studies, 2012), 5

120. White shows that security responses are particularly inefficient on the long term. See ibid. Because the securitization of migration has become a strong cultural assumption in the post-9/11 era, the solution to the inefficiency of these solutions is often, simply, more of the same.

121. Johnstone, "Secretary-General as Norm Entrepreneur."

122. Lesley Wexler, "The International Deployment of Shame, Second-Best Responses, and Norm Entrepreneurship: The Campaign to Ban Landmines and the Landmine Ban Treaty," Arizona Journal of International and Comparative Law 20 (2003): 568.

123. James W. Hansen, Sabine M. Marx, and Elke U. Weber, "The Role of Climate Perceptions, Expectations, and Forecasts in Farmer Decision Making: The Argentine Pampas and South Florida" (Final Report of an IRI Seed Grant Project, 2004).

124. This conclusion is corroborated by Gemenne's observation of the "dominance of the alarmist perspective in the policy subsystem." Gemenne, "How They Became the Human Face," 253.

125. Wendt, Social Theory of International Politics, 315.

126. See, in particular, UNFCCC, decision 1/CP.16, Cancun Agreements: Outcome of the Work of the Ad Hoc Working Group on Long-term Cooperative Action under the Convention (2010), para. 14(f), and decision 3/CP.18, Approaches to address loss and damage associated with climate change impacts in developing countries that are particularly vulnerable to the adverse effects of climate change to enhance adaptive capacity (2012), para. 7(a)(vi); Walter Kälin, "From the Nansen Principles to the Nansen Initiative," Forced Migration 41 (2012): 48.

Benoit Mayer is a PhD candidate at the National University of Singapore. The author may be contacted at bmayer@nus. edu.sg. 
(C) Benoît Mayer, 2014. This open-access work is licensed under a Creative Commons Attribution-NonCommercial 4.0 International License, which permits use, reproduction and distribution in any medium for non-commercial purposes, provided the original author(s) are credited and the original publication in Refuge: Canada's Journal on Refugees is cited. 